\title{
EVALUASI TAMAN R.A KARTINI DILIHAT DARI FUNGSI SOSIAL BAGI KOMUNITAS KREATIF DI KOTA CIMAHI
}

\author{
Wida Oktavia Suciyani, ${ }^{1}$, \\ Husna Candranurani Oktavia ${ }^{2}$ \\ Program Studi D4 Manajemen Aset Politeknik Negeri Bandung ${ }^{1,2}$ \\ Penulis Korespondensi e-mail: wida.oktavia@polban.ac.id
}

\begin{abstract}
Kartini Park has a social function to accommodate the activities of the creative community in the City of Cimahi, but the park does not yet have a special appeal. The purpose of this study is to evaluate the park in terms of social functions for the creative community in the city of Cimahi based on three dimensions of measurement including: structural, interactive and subjective. The research method uses qualitative and quantitative approaches with accidental sampling techniques. The evaluation results on the structural dimension in the form of accessibility show the location of Kartini park is located in a strategic area making it easier for the community to reach the location. As for its use, not all communities in the city of Cimahi use the park as a space for their social interaction, because the facilities are not yet fully adequate. On the interactive dimension, various types of activities of creative communities have been carried out routinely at Kartini Park. Participation from these communities was also good, as evidenced by routine activities held in the park. On the subjectivity dimension, the highest level of community satisfaction is on the security indicator and the lowest satisfaction level is on the completeness indicator of the facility.
\end{abstract}

Keywords: urban garden, social function, creative community

\begin{abstract}
ABSTRAK
Taman Kartini memiliki fungsi sosial untuk mewadahi aktivitas komunitas kreatif di Kota Cimahi, namun taman tersebut belum memiliki daya tarik khusus. Tujuan penelitian ini adalah untuk mengevaluasi taman dilihat dari fungsi sosial bagi komunitas kreatif di kota Cimahi berdasarkan tiga dimensi pengukuran meliputi: struktural, interaktif dan subjektif. Metode penelitian menggunakan pendekatan kualitatif dan kuantitatif dengan teknik accidental sampling. Hasil evaluasi pada dimensi struktural berupa aksesibilitas menunjukkan lokasi taman Kartini berada di kawasan strategis sehingga memudahkan para komunitas untuk mencapai lokasi. Sedangkan untuk penggunaannya, tidak semua komunitas di kota Cimahi menggunakan taman sebagai ruang interaksi sosial mereka, dikarenakan fasilitas yang ada belum sepenuhnya memadai. Pada dimensi interaktif, berbagai jenis aktivitas para komunitas kreatif telah dilaksanakan secara rutin di taman Kartini. Partisipasi dari para komunitas tersebut juga baik, dibuktikan dengan adanya kegiatan rutin yang diselenggarakan di taman. Pada dimensi subjektifitas, tingkat kepuasan komunitas yang tertinggi berada pada indikator keamanan dan tingkat kepuasan terendah pada indikator kelengkapan fasilitas.
\end{abstract}

Kata Kunci: Taman Kota, Fungsi Sosial, Komunitas Kreatif 
Jurnal Planologi Vol. 17 No. 1, April 2020

Available : http://jurnal.unissula.ac.id/index.php/psa

\section{PENDAHULUAN}

Suatu kota idealnya harus dapat memfasilitasi kebutuhan setiap warganya dengan menyuguhkan ruang kota yang aman, nyaman, produktif, dan berkelanjutan. Pemerintah Republik Indonesia melalui Undang-Undang Penataan Ruang Nomor 26 tahun 2007, menghimbau agar setiap kota dapat memenuhi kriteria ideal penyediaan RTH publik sebesar 20\% dari luas wilayahnya. Sejalan dengan peraturan perundangan tersebut, Kementerian Pekerjaan Umum dan Perumahan Rakyat berupaya untuk menjalin kerjasama dengan pemerintah guna mewujudkan ruang kota yang lebih berkualitas melalui Program Pengembangan Kota Hijau (P2KH) dengan bentuk perwujudan kota hijau adalah penyediaan taman kota sebagai RTH publik. RTH dapat dikategorikan sebagai taman yang merupakan sebidang lahan yang ditata sedemikian rupa sehingga mempunyai keindahan, kenyamanan dan keamanan bagi pemiliknya atau penggunanya (Arifin dan Nurhayati, 2000). Pada masyarakat perkotaan, taman-taman selain bernilai estetika juga berfungsi sebagai ruang terbuka. Salah satu kota yang saat ini memiliki program pengembangan fasilitas dan utilitas taman kota yakni Cimahi. Taman yang menjadi prioritas pada program pengembangan fasilitas dan utilitas taman Kota Cimahi adalah taman R.A. Kartini. Lokasi taman R.A. Kartini berada di kawasan Baros yang merupakan kawasan strategis karena mudah dijangkau oleh seluruh lapisan masyarakat di Kota Cimahi. Oleh karenanya, taman R.A. Kartini memiliki potensi untuk mewadahi seluruh lapisan masyarakat/ komunitas untuk memanfaatkan taman sebagai ruang interaksi sosial

Berdasarkan Pedoman Penyediaan dan Pemanfaatan RTH Kawasan Perkotaan (Permen PU No. 05/PRT/M/2008), fungsi RTH terbagi dalam empat jenis yaitu: fungsi ekologis, sosial dan budaya, estetika, serta ekonomi. RTH ekologis merupakan fungsi utama (intrinsik) RTH., sedangkan RTH sosial budaya, estetika, dan ekonomi berperan sebagai fungsi tambahan (ekstrintik). Pengembangan hubungan sosial dalam skala perkotaan harus dimulai dengan perhatian khusus terhadap ruang dengan menggunakan pendekatan desain interaksi. Selain itu, ruang khusus juga dapat digunakan secara efektif untuk mewadahi komunitas sosial di lingkungan masyarakat. Komunitas merupakan suatu kelompok orang yang memiliki minat atau ketertarikan yang sama (Linggasani dan Putra, 2017). Kelompok ini juga memiliki nilai dan tujuan yang sama, sehingga mampu menciptakan interaksi sosial baik antar sesama anggota maupun masyarakat umum.

Komunitas (Communities-of-Practice) adalah sebuah konstruksi sosial yang dibangun berdasar atas initial-interest dan tujuan sama dari seluruh anggotanya (Wenger, 
Jurnal Planologi Vol. 17 No. 1, April 2020

2002). Mereka tidak hanya saling berbagi pengetahuan, namun juga keterampilan. Komunitas kreatif diartikan sebagai sekelompok orang yang memiliki minat khusus atau ketertarikan yang sama terhadap sesuatu yang memiliki nilai dan tujuan, serta dapat menciptakan interaksi yang baik dengan para anggota maupun masyarakat lainnya (Dini dan Fuad, 2014). Komunitas kreatif dapat membuat ruang publik menjadi lebih hidup karena banyakya aktivitas sosial yang dapat mereka selenggarakan di ruang tersebut. Oleh karenanya, komunitas kreatif adalah aktor yang berperan dalam pembentukkan identitas ruang publik di perkotaan.

Taman kota memiliki banyak fungsi seperti fungsi hidrologi, ekologi, kesehatan, estetika dan rekreasi. Diungkapkan pula bahwa taman dapat mejadi sarana kegiatan rekreatif, edukasi atau kegiatan lainnya sebagai fungsi sosial dan estetik (Imansari, 2015). Saat ini taman-taman yang ada di Kota Cimahi telah menjadi ruang beraktivitas bagi beberapa komunitas yang ada di Kota Cimahi. Gagasan kreatif dan inspiratif yang dimunculkan dari komunitas yang terbentuk, dapat menarik pengunjung untuk datang dan menggunakan taman kota untuk ikut terlibat dalam kegiatan komunitas. Taman kota adalah suatu ruang milik bersama tempat melakukan aktivitas dan dikategorikan sebagai bagian dari ruang terbuka public (Carr dalam Darmawan, 2006). Salah satu penggunaan ruang terbuka publik sebagai tempat berkumpul komunitas adalah taman R.A Kartini yang berlokasi di Kota Cimahi. Terdapat 26 komunitas kreatif yang terbentuk di Kota Cimahi dan tujuh komunitas yang menggunakan taman R.A Kartini sebagai tempat kegiatan yaitu komunitas Hayu Maca, Line Dance, Anak Hebat, Pets Family, Zumba Thiefa, Fotografer dan Otomotif. Komunitas kreatif ini bergerak di berbagai macam bidang yang terbagi dalam bidang Edukasi, Keilmuan, Olahraga dan Seni.

Fungsi sosial pada ruang publik dapat diartikan sebagai kegiatan yang membutuhkan kehadiran orang lain (Zhang dan Lawson, 2009). Kegiatan ini dapat berupa pertemuan dan perbincangan santai di pinggir jalan, maupun kegiatan anak-anak bermain di taman kota. Penanganan ruang publik yang kreatif juga dapat mendukung terbentuknya aktivitas sosial dari para komunitas kreatif. Kegiatan-kegiatan kreatif yang diselenggarakan di ruang-ruang terbuka (baik yang bertujuan komersial maupun non-komersial). Guna mengevaluasi fungsi sosial dalam kajian ruang publik seperti taman kota, dapat diukur melalui tiga dimensi, sebagaimana ditunjukkan pada Gambar 1. 
Jurnal Planologi Vol. 17 No. 1, April 2020

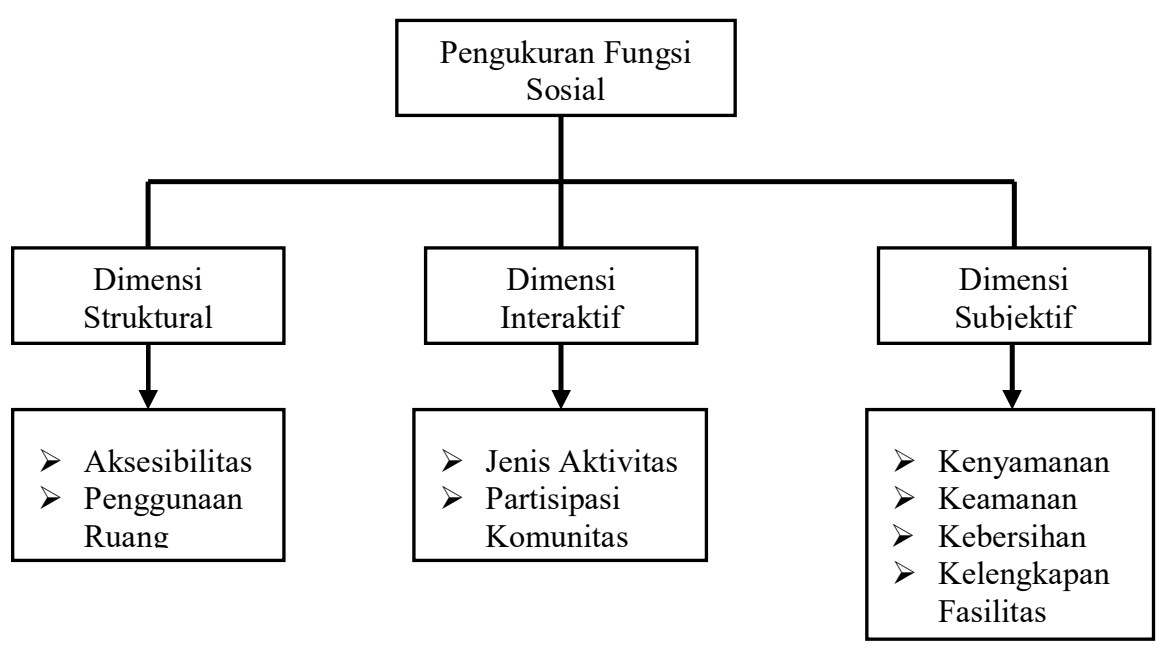

Gambar 1. Dimensi dan Indikator Pengukuran Fungsi Sosial Ruang Publik Sumber: Sautter dan Huettenmoser, 2008

Berdasarkan survey pendahuluan, taman Kartini belum memiliki tema yang spesifik untuk mewadahi komunitas, sehingga belum memiliki daya tarik khusus. Oleh karenanya, penelitian ini dimaksudkan untuk mengevaluasi fungsi sosial taman Kartini untuk mewadahi fungsi sosial komunitas kreatif di Kota Cimahi dan mengetahui persepsi komunitas kreatif di kota Cimahi sebagai pengguna taman terhadap pemenuhan kriteria fungsi sosial taman kota.

Adapun pertanyaan penelitian adalah apakah dimensi struktural (aksesibilitas dan penggunaan) sudah dapat memfasilitasi kebutuhan komunitas kreatif; apakah dimensi interaktif (aktivitas dan partisipasi) komunitas kreatif sudah berjalan dengan baik di taman. Kartini; dan bagaimana dimensi subjektif (kepuasan dan persepsi komunitas kreatif) terhadap pengelolaan lingkungan taman Kartini. Ruang lingkup penelitian ini adalah RTH publik berupa taman kota dan komunitas kreatif di Kota Cimahi sebagai pengguna taman. Taman dan pengunjungnya dipilih guna meninjau keefektivan fungsi sosial taman kota yang sudah ada saat ini dan untuk mengetahui persepsi komunitas kreatif di kota Cimahi sebagai pengguna taman terhadap pemenuhan kriteria fungsi sosial taman kota.

\section{METODOLOGI}

Metode yang digunakan adalah metode deskriptif dengan menggunakan pendekatan kombinasi antara kualitatif dan kuantitatif. Metode kuantitatif merupakan studi mengenai suatu masalah yang berdasarkan pada data dan analisis berupa angka-angka, sedangkan metode kualitatif berarti suatu penelitian mengenai sebuah permasalahan dengan berdasarkan pada data dan analisis yang tidak berupa angka (Sugiama , 2008). Metode 
deskriptif kualitatif pada penelitian ini digunakan dalam melakukan analisa kondisi eksisting taman Kartini. Sedangkan metode deskriptif kuantitatif digunakan untuk mengevaluasi fungsi sosial taman Kartini sebagai RTH publik Kota Cimahi yang berdasarkan pada persepsi komuitas kreatif sebagai pengunjung taman. Teknik sampling pada penelitian ini adalah accidental sampling, yaitu responden atau komunitas kreatif yang secara kebetulan/insidental bertemu di taman dengan peneliti dan dianggap cocok dan dapat mewakili sebagai sumber data. Data yang terkumpul akan dianalisis dengan menggunakan teknik analisis kuantitatif dan kualitatif. Data kuantitatif akan dianalisis dengan menggunakan metode statistik deskriptif (mean values, percentages dan standard deviation). Metode ini digunakan untuk memahami pola distribusi dan kecenderungan data dari pengunjung taman. Di samping itu, data kualitatif yang diperoleh dari wawancara, pengamatan, dan pertanyaan terbuka dalam angket, akan dianalisis dengan teknik content analysis

\section{HASIL DAN PEMBAHASAN}

\subsection{Gambaran Umum Taman R.A Kartini}

Taman R.A. Kartini merupakan Ruang Terbuka Hijau (RTH) publik di kota Cimahi yang berlokasi di Jalan Baros Kelurahan Utama Kecamatan Cimahi Tengah dengan luas lahan sebesar 0,6 Ha $\left(6.500 \mathrm{~m}^{2}\right)$. Pada awalnya, taman Kartini ini diberi nama taman Wilhelmina dimana nama tersebut diambil dari nama Ratu Kerajaan Belanda kala itu.

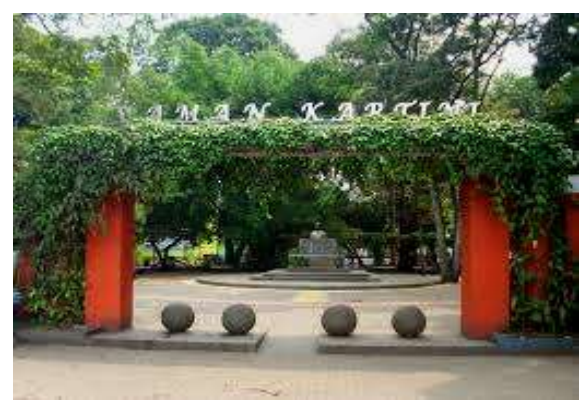

Gambar 2. Taman R.A Kartini Sumber : google.com, 2019

Namun pada era kemerdekaan, taman tersebut telah berganti nama menjadi Taman R.A. Kartini. Taman R.A Kartini merupakan ruang publik yang dapat diakses oleh semua lapisan masyarakat kota Cimahi dan sekitarnya, hal tersebut dikarenakan tempat ini bebas dikunjungi oleh siapapun tanpa ada pungutan biaya. Selain itu, keberadaan Taman Kartini 
telah menjadikan ruang bagi komunitas kreatif di kota Cimahi untuk menjalankan berbagai aktivitas di taman tersebut. Berdasarkan informasi dari salah satu komunitas, terdapat 26 komunitas yang aktif dalam forum komunitas kota Cimahi. Akan tetapi tidak semua komunitas menjadikan Taman Kartini sebagai ruang interaksi sosial mereka dikarenakan berbagai hal. Adapun kegiatan yang dilakukan oleh para komunitas di Taman Kartini, sebagaimana ditunjukkan pada Gambar 3.

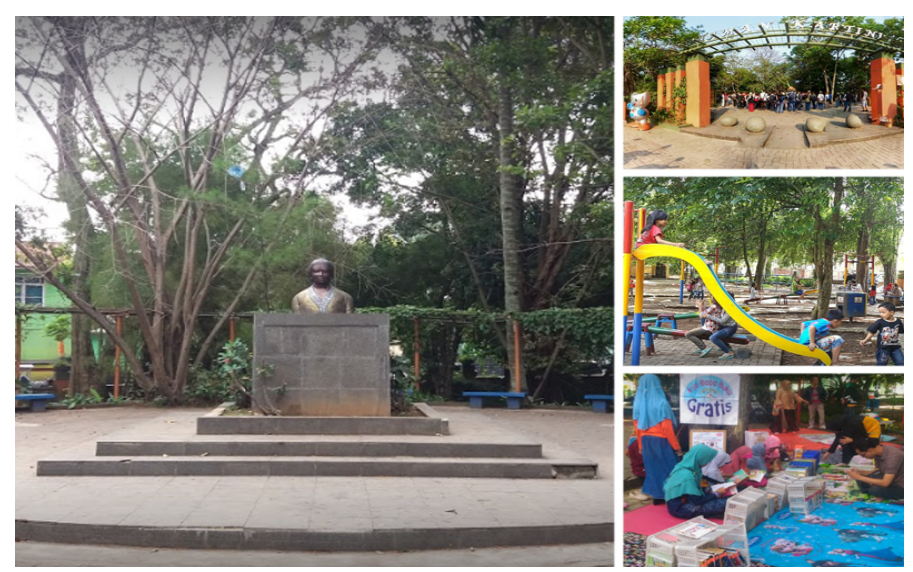

Gambar 3. Ruang Interaksi Sosial Taman Kartini Sumber: wisatabdg.com, 2019

\subsection{Dimensi Struktural Taman R.A Kartini}

Dimensi struktural merupakan salah satu aspek yang dapat digunakan untuk mengukur fungsi sosial ruang publik (Sauter dan Huettenmoser, 2008). Dimensi tersebut mengkaji suatu aksesibilitas dan penggunaan ruang publik dalam memfasilitasi kebutuhan sosial masyarakat sekitar. Oleh karenanya, penelitian mengenai evaluasi fungsi sosial taman Kartini, dilakukan dengan mengkaji aksesibilitas dan penggunaan taman bagi komunitas kreatif di Kota Cimahi. Hal tersebut dimaksudkan untuk mengetahui apakah taman R.A. Kartini telah berfungsi sebagai ruang publik dengan fungsi sosial yang dapat mengakomodasi para komunitas kreatif dalam menjalankan aktivitasnya.

\subsubsection{Aksesibilitas Taman R.A Kartini}

Aksesibilitas ruang terbuka merupakan kemudahan pengguna dalam memasuki taman secara fisik dan pencapaian taman secara visual (Salih \& Ismail, 2017). Aksesibilitas menuju Taman Kartini dapat dijangkau oleh masyarakat dengan menggunakan beberapa moda transportasi, termasuk angkutan umum. Berdasarkan hasil observasi, terdapat 6 trayek angkutan umum yang melewati lokasi Taman, sebagaimana ditunjukkan pada Gambar 4. 


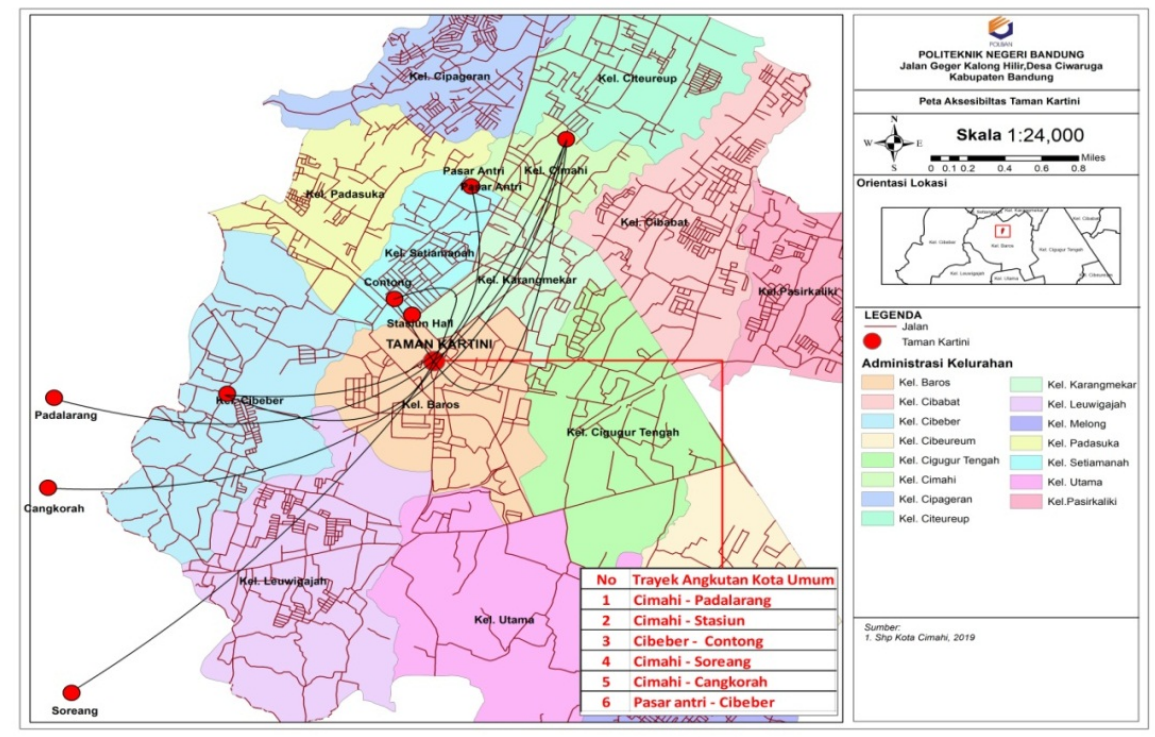

Gambar 4. Peta Aksesibilitas Taman R.A Kartini Sumber: Observasi, 2019

Trayek angkutan umum yang melewati Taman Kartini berasal dari beberapa daerah dengan rute trayek sebagai berikut: angkutan umum Cimahi-Padalarang; Cimahi-Stasiun Bandung; Cibeber-Contong; Cimahi-Soreang; Cimahi-Cangkorah; dan Pasar AndirCibeber. Dengan beragamnya rute trayek angkutan umum yang dapat melewati Taman Kartini, menunjukkan bahwa Taman R.A. Kartini dapat diakses oleh berbagai masyarakat dari beberapa penjuru Kota Cihami. Selain itu, Taman Kartini yang berada di jalur utama jalan Baros, berada pada lokasi yang strategis karena berdekatan dengan stasiun Kereta Api Cimahi dan gerbang tol Baros yang dapat ditempuh dengan jarak $1 \mathrm{~km}$ (5 menit).

\subsubsection{Penggunaan Taman R.A Kartini}

Taman merupakan RTH yang memiliki fungsi sebagai wadah yang disediakan untuk masyarakat dalam menjalankan aktivitas sosial (Salih \& Ismail, 2017). Guna menunjang aktivitas sosial masyarakat tersebut, diperlukan beberapa fasilitas yang harus ada di dalam taman. Salah satu pemenuhan kriteria yang harus dipenuhi oleh taman dalam meningkatkan interaksi sosial adalah ketersediaan fasilitas, sebagaimana ditunjukkan pada Tabel 1. 
Jurnal Planologi Vol. 17 No. 1, April 2020

Available : http://jurnal.unissula.ac.id/index.php/psa

Tabel 1. Fasilitas Pada Taman R.A Kartini

\begin{tabular}{|c|c|c|c|c|c|}
\hline No & Fasilitas & $\begin{array}{c}\text { Jumlah/ } \\
\text { unit }\end{array}$ & Ketersediaan & Lokasi & Foto \\
\hline 1 & Zebra Cross & - & $\mathrm{X}$ & Tidak ada & \\
\hline 2 & Trotoar & - & $\checkmark$ & $\begin{array}{l}\text { Terdapat diarea } \\
\text { luar sekitar taman }\end{array}$ & \\
\hline 3 & $\begin{array}{l}\text { Halte Kenda- } \\
\text { raan umum }\end{array}$ & - & $\mathrm{X}$ & Tidak ada & \\
\hline 4 & $\begin{array}{l}\text { Rambu dan } \\
\text { Marka }\end{array}$ & 5 & $\checkmark$ & $\begin{array}{l}\text { Terdapat didepan } \\
\text { taman pada } \\
\text { beberapa titik. }\end{array}$ & \\
\hline 5 & $\begin{array}{l}\text { Pos Keamanan } \\
\text { (Pusen Armed } \\
\text { TNI AD) }\end{array}$ & 1 & $\checkmark$ & $\begin{array}{l}\text { Terdapat didepan } \\
\text { taman }\end{array}$ & \\
\hline 6 & Lampu Taman & 15 & $\checkmark$ & $\begin{array}{lr}\text { Terdapat } & \text { di } \\
\text { sepanjang } & \text { jalur } \\
\text { pejalan } & \text { kaki } \\
\text { didalam taman. }\end{array}$ & \\
\hline 7 & $\begin{array}{c}\text { Jalur Pejalan } \\
\text { Kaki }\end{array}$ & & $\checkmark$ & $\begin{array}{l}\text { Jalur pejalan kaki } \\
\text { terdapat diarea } \\
\text { taman }\end{array}$ & \\
\hline 8 & $\begin{array}{l}\text { Jalur } \\
\text { Pemandu/ } \\
\text { Guiding Block }\end{array}$ & - & $\mathrm{X}$ & $\begin{array}{l}\text { Tidak terdapat } \\
\text { guiding } \text { block } \\
\text { untuk memandu } \\
\text { para penyandang } \\
\text { disabilitas }\end{array}$ & - \\
\hline 9 & Handrail & - & $\mathrm{X}$ & Tidak ada & - \\
\hline
\end{tabular}


Jurnal Planologi Vol. 17 No. 1, April 2020

Available : http://jurnal.unissula.ac.id/index.php/psa

\begin{tabular}{|c|c|c|c|c|c|}
\hline No & Fasilitas & $\begin{array}{c}\text { Jumlah/ } \\
\text { unit }\end{array}$ & Ketersediaan & Lokasi & Foto \\
\hline 10 & Tempat Duduk & 31 & $\checkmark$ & $\begin{array}{l}\text { Tedapat diseluruh } \\
\text { area taman. }\end{array}$ & \\
\hline 12 & $\begin{array}{l}\text { Fasilitas Area } \\
\text { Bermain }\end{array}$ & 7 & $\checkmark$ & $\begin{array}{lr}\text { Terdapat } & \text { pada 1 } \\
\text { titik } & \text { taman } \\
\text { bermain } & \text { untuk } \\
\text { anak } & \text { seperti: } \\
\text { ayunan, } & \text { jungkat- } \\
\text { jangkit, } & \text { dan } \\
\text { perosotan. } & \end{array}$ & \\
\hline 13 & $\begin{array}{l}\text { Fasilitas } \\
\text { Peribadatan }\end{array}$ & 1 & $\checkmark$ & $\begin{array}{l}\text { Terdapat } \\
\text { disamping toilet } \\
\text { umum di sebelah } \\
\text { barat taman } \\
\text { kartini. }\end{array}$ & \\
\hline 14 & $\begin{array}{c}\text { Fasilitas } \\
\text { Tempat Parkir }\end{array}$ & 1 & $\checkmark$ & $\begin{array}{l}\text { Terdapat didepan } \\
\text { pintu gerbang } \\
\text { masuk taman. }\end{array}$ & \\
\hline 15 & $\begin{array}{c}\text { Pusat } \\
\text { Informasi }\end{array}$ & - & $\mathrm{X}$ & Tidak ada & \\
\hline 16 & Toilet & 2 & $\checkmark$ & $\begin{array}{l}\text { Terdapat } \\
\text { disebelah barat } \\
\text { taman yang dibagi } \\
\text { menjadi 2, yaitu } \\
\text { untuk pria dan } \\
\text { wanita }\end{array}$ & \\
\hline 17 & $\begin{array}{l}\text { Fasilitas } \\
\text { Kebersihan }\end{array}$ & 19 & $\checkmark$ & $\begin{array}{l}\text { Fasiltas } \\
\text { kebersihan berupa } \\
\text { petugas } \\
\text { kebersihan dan } \\
\text { tong sampah yang } \\
\text { tersebar di seluruh } \\
\text { area taman. }\end{array}$ & \\
\hline
\end{tabular}




\begin{tabular}{llccll}
\hline No & \multicolumn{1}{c}{ Fasilitas } & $\begin{array}{c}\text { Jumlah/ } \\
\text { unit }\end{array}$ & Ketersediaan & \multicolumn{1}{c}{ Lokasi } & Foto \\
\hline 18 & $\begin{array}{l}\text { Fasilitas Akses } \\
\text { Internet }\end{array}$ & - & $\mathrm{X}$ & $\begin{array}{l}\text { Belum terdapat } \\
\text { akses internet di } \\
\text { taman kartini }\end{array}$ & - \\
\hline 19 & $\begin{array}{l}\text { Fasilitas } \\
\text { Olahraga }\end{array}$ & 1 & $\checkmark$ & $\begin{array}{l}\text { Terdapat 2 } \\
\text { fasilitas olah raga } \\
\text { yaitu skateboard } \\
\text { proses kontruksi } \\
\text { dan lapnagan bola } \\
\text { kecil. }\end{array}$ \\
& & & $\begin{array}{l}\text { Vegetasi berupa } \\
\text { pohon-pohon dan } \\
\text { bunga-bunga } \\
\text { disekitar taman } \\
\text { kartini. }\end{array}$ \\
\hline 20 & Vegetasi & $\checkmark$ &
\end{tabular}

Sumber: Analisis Penyusun, 2019

Berdasarkan hasil observasi terdapat beberapa fasilitas yang sudah terpenuhi, namun terdapat juga beberapa fasilitas yang belum terpenuhi meliputi: tempat ibadah; zebra cross; halte kendaraan umum; jalur pemandu; handrail; pusat informasi dan fasilitas akses internet. Oleh karenanya guna memenuhi pelayanan fungsi sosial, diperlukan penambahan terhadap fasilitas yang belum tersedia. Hal tersebut dapat menjadi daya tarik bagi komunitas kreatif yang ada di Kota Cimahi untuk menggunakan taman Kartini sebagai wadah untuk melangsungkan kegiatan komunitas.

\subsection{Dimensi Interaktif Taman R.A Kartini}

Dimensi interaktif merupakan salah satu aspek yang dapat digunakan untuk mengukur fungsi sosial ruang publik (Sauter dan Huettenmoser, 2008). Oleh karenanya pada penelitian ini, dimensi tersebut digunakan untuk mengkaji jenis aktivitas komunitas kreatif sebagai pengguna Taman Kartini dan untuk mengidentifikasi adanya kemungkinan partisipasi dari masyarakat sekitar. Berikut merupakan pemaparan hasil evaluasi fungsi sosial taman berdasarkan jenis aktivitas dan partisipasi komunitas kreatif di Taman RA Kartini.

\subsubsection{Jenis Aktivitas di Taman Kartini}

Berdasarkan hasil observasi, Taman Kartini memiliki desain ruang dengan 3 zonasi kawasan, meliputi: zona belajar dan olahraga; zona bermain; serta zona keluarga. Ketiga zona tersebut sangat mendukung keberadaan taman sebagai fungsi sosial di masyarakat khususnya dalam menunjang kegiatan yang dilakukan oleh komunitas kreatif di taman tersebut. Zona pertama di Taman RA Kartini adalah zona belajar dan olahraga atau yang biasa disebut zona edukasi. Zona tersebut tercipta sebagai tempat belajar dan olahraga 
karena kehadiran komunitas kreatif yang rutin beraktivitas di Taman R.A. Kartini. Jenis aktivitas pada zona edukasi antara lain kegiatan bedah buku, membaca buku, mendengarkan dongeng, senam pagi, dan olah raga skateboard. Visualisasi dari zona edukasi, sebagaimana ditunjukkan pada Gambar 5.

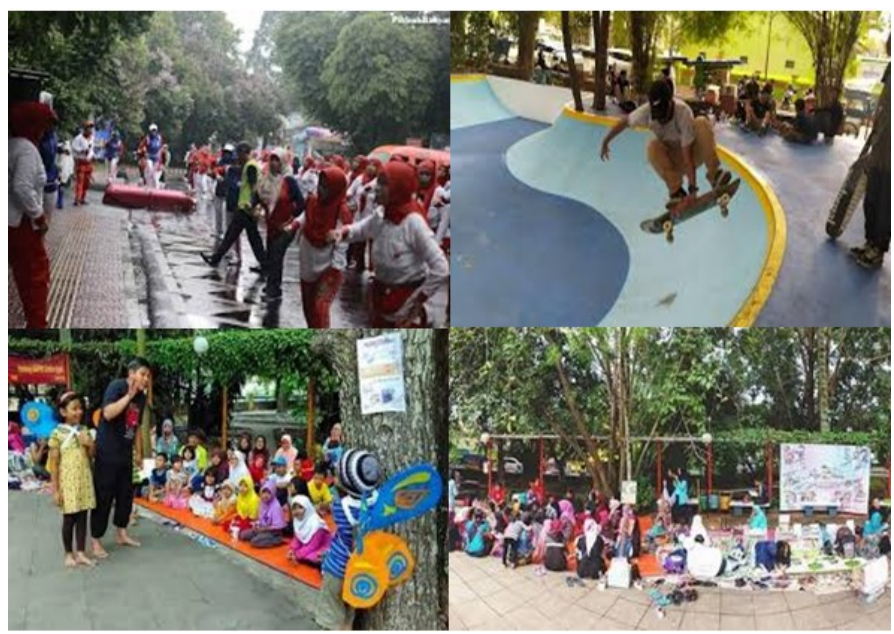

Gambar 5. Zona Edukasi Taman R.A Kartini sumber: google.com, 2019

Zona bermain yang berlokasi di sebelah barat zona edukasi. Zona bermain merupakan zona khusus yang diperuntukan bagi anak-anak. Berdasarkan hasil observasi, terdapat berbagai fasilitas yang menunjang aktivitas bermain anak seperti ayunan dan perosotan, serta spot khusus menggambar dan mewarnai. Selain itu, zona bermain juga menyediakan spot dengan area hijau bagi pengunjung yang ingin bersantai atau sekadar menikmati makanan dan minuman di suasana taman yang rindang. Visualisasi zona bermain di Taman RA Kartini Cimahi, sebagaimana ditunjukkan pada Gambar 6.

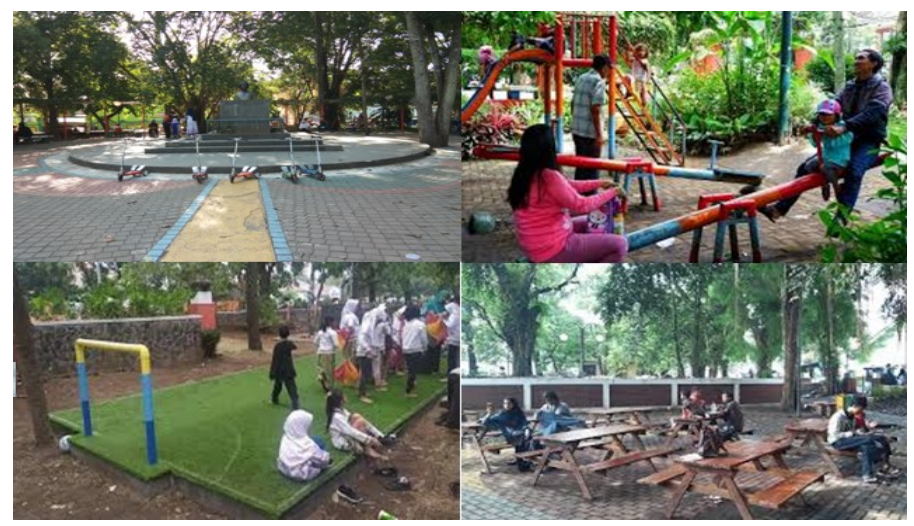

Gambar 6. Zona Bermain Taman Kartini sumber: google.com, 2019 
Zona terakhir adalah zona keluarga sebagai area terluas di taman tersebut. Zona keluarga diperuntukan bagi masyarakat atau pengunjung yang bermaksud untuk mengadakan rekreasi keluarga. Hal tersebut didukung oleh berbagai fasilitas yang tersedia di zona keluarga, seperti adanya beberapa gazebo di bawah pepohonan yang rindang, tempat duduk untuk bersantai, arena kolam yang masih dalam proses pengerjaan, serta fasilitas terapi yang terbuat dari bebatuan. Hal tersebut dapat menambah daya dukung taman terhadap aktivitas masyarakat, khususnya untuk para komunitas yang membawa serta sanak keluarganya. Visualisasi zona keluarga di Taman Kartini, sebagaimana ditunjukkan pada Gambar 7.

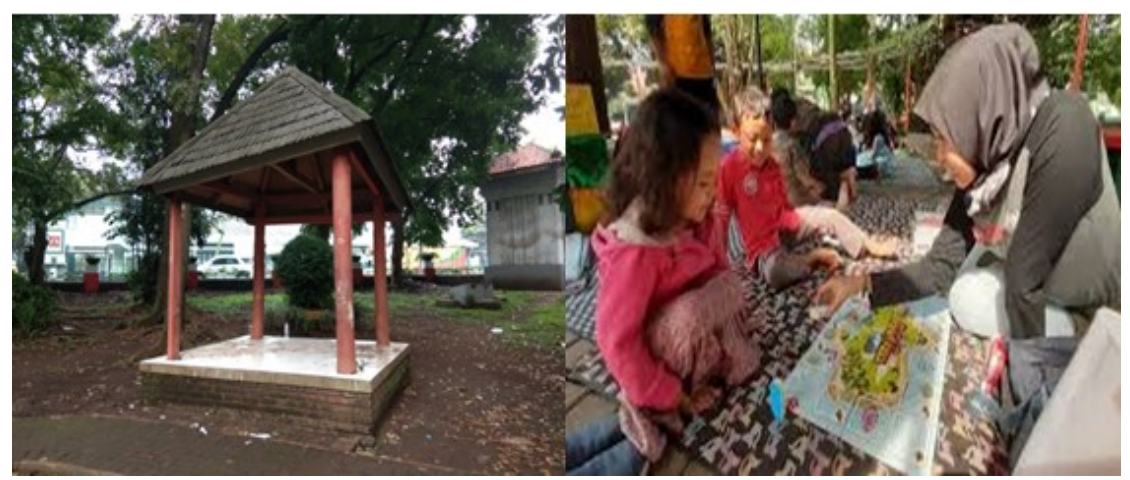

Gambar 7. Zona Keluarga Taman Kartini sumber: google.com, 2019

\subsubsection{Partisipasi Komunitas di Taman Kartini}

Berdasarkan hasil observasi, Taman RA Kartini telah memiliki komunitas kreatif yang berjalan dengan baik. Hal tersebut dapat dilihat dari berbagai komunitas yang rutin melakukan kegiatan di Taman RA Kartini. Komunitas yang dimaksud meliputi komunitas Line Dance, Hayu Maca, Anak Hebat, Pet's Family, Zumba Thiefa, Fotografi, dan Komunitas Club Motor Sport. Di samping itu, komunitas tersebut telah berhasil menciptakan keterlibatan masyarakat, sehingga kehadirannya mampu menghidupkan fungsi sosial bagi Taman RA Kartini. dapat diketahui bahwa jenis aktivitas dan partisipasi komunitas kreatif di Taman RA Kartini telah berjalan dengan baik. Hal tersebut dapat dilihat dari enam komunitas yang telah memiliki kegiatan rutin bahkan telah melaksanakan event besar di Taman RA Kartini. Di samping itu, terdapat tiga dari enam komunitas yang telah melibatkan masyarakat dan pengunjung taman dalam kegiatannya. Adapun profil komunitas sebagaimana ditunjukkan Pada Tabel 2. 
Jurnal Planologi Vol. 17 No. 1, April 2020

Available : http://jurnal.unissula.ac.id/index.php/psa

Tabel 2. Profil Komuintas Kreatif di Taman Kartini

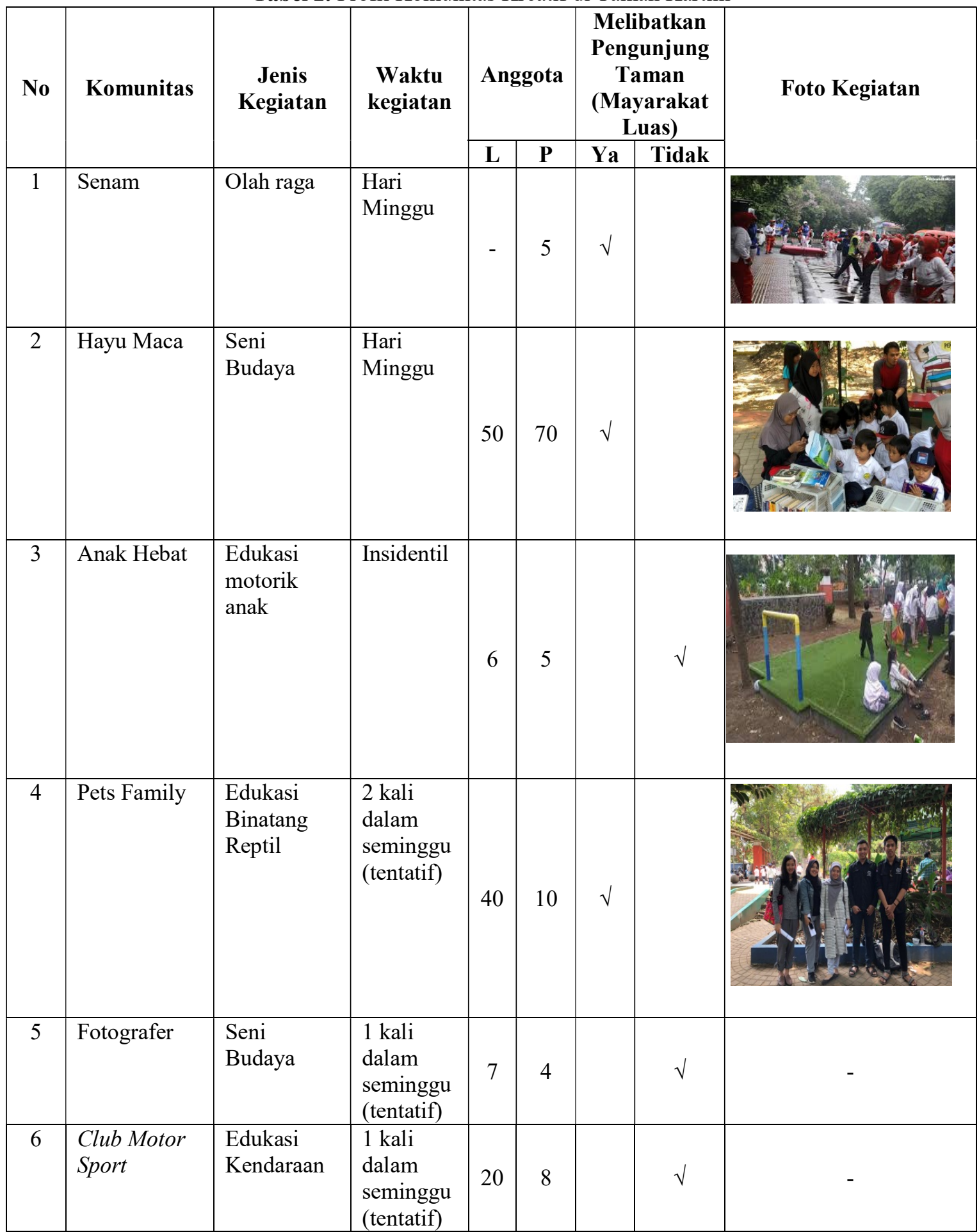

Sumber: Analisis Penyusun, 2019 
Jurnal Planologi Vol. 17 No. 1, April 2020

Available : http://jurnal.unissula.ac.id/index.php/psa

\subsection{Dimensi Subjektif Taman Kartini}

Dimensi subjektif dimaksudkan untuk mengukur kepuasan dan persepsi pengunjung (komunitas kreatif) terhadap pengelolaan lingkungan di taman R.A Kartini Kota Cimahi (Sauter dan Huettenmoser, 2008). Kepuasan dan persepsi diukur melalui indikator kenyamanan, keamanan, kebersihan dan kelengkapan fasilitas (Project for Public Spaces, 2012). Terdapat empat indikator yang diukur dalam dimensi subjektif yaitu kenyamanan, keamanan, kebersihan dan kelengkapan fasilitas di Taman Kartini. Berikut merupakan hasil persentase tingkat kepuasan komunitas kreatif yang dimuat pada Tabel 3.

Tabel 3. Persentase Tingkat Kepuasan

\begin{tabular}{lccccc}
\hline \multirow{2}{*}{ Indikator } & \multicolumn{5}{c}{ Persentase Tingkat Kepuasan } \\
\cline { 2 - 6 } & $\begin{array}{c}\text { Tidak } \\
\text { Puas }\end{array}$ & $\begin{array}{c}\text { Kurang } \\
\text { Puas }\end{array}$ & $\begin{array}{c}\text { Cukup } \\
\text { Puas }\end{array}$ & Puas & $\begin{array}{c}\text { Sangat } \\
\text { Puas }\end{array}$ \\
\hline Kenyamanan & - & - & $14 \%$ & $72 \%$ & $14 \%$ \\
\hline Keamanan & - & - & - & $14 \%$ & $86 \%$ \\
\hline Kebersihan & - & $14 \%$ & $57 \%$ & $29 \%$ & - \\
\hline $\begin{array}{l}\text { Kelengkapan } \\
\text { Fasilitas }\end{array}$ & - & $72 \%$ & $14 \%$ & $14 \%$ & - \\
\hline
\end{tabular}

Berdasarkan hasil analisis data yang diperoleh dari hasil survey kepada responden sebanyak 6 komunitas kreatif yang mengunjungi Taman RA Kartini, diketahui bahwa indikator pengukuran kepuasan yang mendapat penilaian tertinggi adalah keamanan. Hal tersebut dipengaruhi oleh letak Taman R.A. Kartini yang berhadapan dengan gedung Kodiklat TNI Angkatan Darat Pusat Kesenjataan Artileri Medan (Pussen Armed) dan juga adanya pengamanan yang dilakukan secara rutin oleh petugas untuk selalu memantau keamanan di Taman Kartini. Oleh karena itu, komunitas merasa aman dengan adanya petugas TNI yang berjaga di pintu utama Pussen Armed. Selain itu, sampai saat ini tidak terdapat peristiwa kriminal yang terjadi di Taman RA Kartini.

Indikator dengan penilaian paling rendah adalah kelengkapan fasilitas. Komunitas menilai fasilitas yang tersedia belum dapat memenuhi kebutuhan dan terdapat sejumlah fasilitas yang belum tersedia seperti tempat ibadah; zebra cross; halte kendaraan umum; jalur pemandu; handrail; pusat informasi dan fasilitas akses internet . Beberapa fasilitas yang tersedia namun kondisinya belum dapat memenuhi kebutuhan komunitas adalah tempat sampah dan tempat parkir. Kondisi tempat sampah yang tersedia saat ini jumlahnya terbatas sehingga tidak dapat menampung banyaknya produksi sampah. Selain itu, kondisi tempat sampah tidak dilengkapi dengan penutup tempat sampah, hal ini menyebabkan sampah yang menunpuk dapat kembali berceceran. 
Jurnal Planologi Vol. 17 No. 1, April 2020

Available : http://jurnal.unissula.ac.id/index.php/psa

\section{KESIMPULAN DAN SARAN}

\subsection{Kesimpulan}

Hasil evaluasi taman R.A Kartini sebagai fungsi sosial bagi komunitas kreatif di kota Cimahi, menunjukkan bahwa pada dimensi struktural berupa aksesibilitas menunjukkan lokasi taman Kartini berada di kawasan strategis sehingga memudahkan para komunitas kreatif dan masyarakat sekitar mudah untuk mencapai lokasi tersebut. Sedangkan untuk penggunaan taman, tidak semua komunitas di kota Cimahi menggunakan taman Kartini sebagai ruang interaksi sosial mereka, dikarenakan fasilitas yang ada belum sepenuhnya menunjang para komunitas kreatif di Kota Cimahi. Pada dimensi interaktif, berbagai jenis aktivitas para komunitas kreatif telah dilaksanakan secara rutin di taman Kartini. Partisipasi dari para komunitas tersebut juga baik, dibuktikan dengan adanya kegiatan rutin yang diselenggarakan di taman. Pada dimensi subjektifitas, tingkat kepuasan komunitas yang tertinggi berada pada indikator keamanan dan tingkat kepuasan terendah pada indikator kelengkapan fasilitas.

\subsection{Saran}

Berdasarkan kesimpulan penelitian ditemukan adanya kekurangan dari segi fasilitas meliputi: tempat ibadah; zebra cross; halte kendaraan umum; handrail; pusat informasi dan fasilitas akses internet pada taman Kartini dalam menunjang fungsi sosial bagi komunitas kreatif. Selain itu, Taman Kartini belum ramah terhadap kaum disabilitas, kareana tidak memiliki guiding block untuk memandu para penyandang disabilitas. Oleh karenanya, perlu dilakukan penelitian lanjutan mengenai pengembangan terhadap fasilitas di Taman R.A Kartini, guna meningkatkan partisipasi komunitas kreatif dalam penggunaan taman sebagai fungsi sosial, sehingga fungsi taman menjadi lebih optimal.

\section{DAFTAR PUSTAKA}

Arifin, H. S. A dan Nurhayati. (2000). Pemeliharaan Taman. Penebar Swadaya. Jakarta. Badan Pusat Statistik Kota Cimahi. 2016. Jumlah Penduduk Kota Cimahi.

Darmawan E. (2006). Teori dan Kajian Ruang Publik Kota. Badan Penerbit Universitas Diponegoro. Semarang.

Dini dan Fuad. (2014). Peran Komunitas Kreatif Dalam Pembentukkan Identitas Ruang Publik. Jakarta: FT UI. 
Imansari, N., dan Khadiyanta, P. (2015). Penyediaan hutan kota dan taman kota sebagai ruang terbuka hijau $(\mathrm{RTH})$ publik menurut preferensi masyarakat di kawasan pusat Kota Tangerang. Ruang, 1(3), 101-110.

Linggasani dan Putra. (2017). Pembentukan identitas ruang oleh suatu komunitas kreatif di ruang publik (area car free day) Dago, Bandung. Jurnal ilmiah Arsitektur, 5(2), $27-$ 32.

Peraturan Menteri Pekerjaan Umum No 5 Tahun 2008 tentang Pedoman Penyediaan Pemanfaatan Ruang Terbuka Hijau di Kawasan Perkotaan.

Sari, Indah Kumala. (2017). Perencanaan Kebbutuhan Aset Ruang Terbuka Hijau Publik di Kota Cimahi. Bandung: Polteknik Negeri Bandung.

Sauter dan Huettenmoser. (2008). Liveable street and social inclusion. Urban design international (2008), volume 13, 67-70.www.palgrave-journals.co.uk/udi.

Shalih dan Ismail. International Conference on Architecture and Civil Engineering (ICACE 2017) IOP Publishing IOP Conf. Series: Materials Science and Engineering 291 (2017) 012001 doi:10.1088/1757-899X/291/1/012001.

Sugiama, A.G. (2008). Metode Riset Bisnis dan Manajemen (Edisi pertama). Bandung: Guardaya Intimarta.

UU No.26 Tahun 2007 tentang Penataan Ruang.

Wenger, Etienne et al. (2002). Cultivating Communities of Practice. Harvard Business School Press.

Zhang dan Lawson. (2009). Meeting and greeting: activities in public outdoor spaces outside high-density urban residential communities. Urban design international (2009), volume 14, 4, 207-214. 